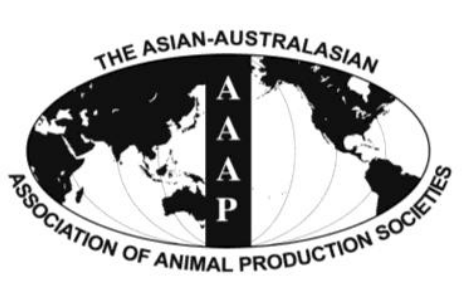

Open Access

Asian Australas. J. Anim. Sci.

Vol. 27, No. 12 : 1773-1782 December 2014

http://dx.doi.org/10.5713/ajas.2014.14069

www.ajas.info

pISSN 1011-2367 elSSN 1976-5517

\title{
Meat Quality Characteristics of Small East African Goats and Norwegian Crosses Finished under Small Scale Farming Conditions
}

\author{
W. A. Hozza*, L. A. Mtenga, G. C. Kifaro, D. S. N. Shija, D. E. Mushi, J. G. Safari ${ }^{1}$, and E. J. M. Shirima ${ }^{2}$ \\ Department of Animal Science and Production, Sokoine University of Agriculture, Morogoro, Tanzania
}

\begin{abstract}
The aim of the experiment was to study the effect of feeding system on meat quality characteristics of Small East African (SEA) goats and their crosses with Norwegian $(\mathrm{SEA} \times \mathrm{N})$ goats finished under small scale farming conditions. Twenty four castrated goats at the age of 18 months with live body weight of $16.7 \pm 0.54 \mathrm{~kg}$ from each breed (SEA and SEA $\times \mathrm{N}$ ) were distributed in a completely randomized design in a $2 \times 3$ factorial arrangement (two breed, and three dietary treatments). The dietary treatments were; no access to concentrate (T0), 66\% access to ad libitum concentrate allowance (T66) and 100\% access to ad libitum concentrate allowance with $20 \%$ refusal (T100) and the experimental period was for 84 days. In addition, all goats were allowed to graze for 2 hours daily and later fed grass hay on ad libitum basis. Daily feed intakes were recorded for all 84-days of experiment after which the animals were slaughtered. Feed intake of T100 animals was $536 \mathrm{~g} / \mathrm{d}$, which was $183 \mathrm{~g} / \mathrm{d}$ higher than that of T66 group. Supplemented goats had significantly $(\mathrm{p}<0.05)$ better feed conversion efficiency. The SEA had higher $(\mathrm{p}<0.05)$ hot carcass weight $(8.2 \mathrm{vs} 7.9 \mathrm{~kg})$, true dressing percentage (54.5 vs 53.3) and commercial dressing percentage (43.3 vs 41.6 ) compared to SEA $\times \mathrm{N}$. There was no significant difference ( $>0.05$ ) for dressing percentage and carcass conformation among supplemented goats except fatness score, total fat depots and carcass fat which increased $(\mathrm{p}<0.05)$ with increasing concentrate levels in the diet. Increasing level of concentrate on offer increased meat dry matter with subsequent increase of fat in the meat. Muscle $\mathrm{pH}$ of goats fed concentrate declined rapidly and reached below 6 at $6 \mathrm{~h}$ postmortem but temperature remained at $28^{\circ} \mathrm{C}$. Cooking loss and meat tenderness improved $(\mathrm{p}<0.05)$ and thawing loss increased $(\mathrm{p}<0.05)$ with ageing period. Similarly, meat tenderness improved $(\mathrm{p}<0.05)$ with concentrate supplementation. Shear force of muscles varied from 36 to 66, the high values been associated with Semimembranosus and Gluteobiceps muscles. The present study demonstrates that there are differences in meat quality characteristics of meat from SEA goats and their crosses with Norwegian breeds finished under small scale farming conditions in rural areas. Therefore, concentrate supplementation of goats of both breeds improves meat quality attributes. (Key Words: Concentrate Supplementation, Fattening, Goats, Meat Quality)
\end{abstract}

\section{INTRODUCTION}

The demand for quality meat in Tanzania is growing due to expanding markets composed of tourism, mining industries, expatriates as well as increased income and purchasing power of the society (Mushi et al., 2006). The importance of goat farming has increased due to their fast

\footnotetext{
* Corresponding Author: W. A. Hozza. Tel: +255-756166124, Fax: +255-232604562, E-mail: hozzaw@yahoo.com

${ }^{1}$ Institute of Rural Development Planning, Dodoma, 41000 Tanzania.

${ }^{2}$ Ministry of Livestock and Fisheries Development, Dar-esSalaam 11000, Tanzania.

Submitted Jan. 27, 2014; Revised Mar. 24, 2014; Accepted May 19, 2014
}

economic return. Goats provide more meat and milk per unit live weight per year than other large ruminants. Goat production in tropical countries involves grazing on natural pastures whose availability and quality is highly variable. Moreover, these animals produce poor carcasses of low quality meat (low carcass weight, poor conformation and tenderness). Nutrition and management are considered crucial in determining the quantity, quality and economics of meat production (Agnihotri et al., 2006). Although there is now a considerable number of a published research on indigenous types of small ruminants in tropical areas of Africa, much of the published work has the disadvantage of having been carried out under controlled conditions at research stations and the results may not reflect the actual 
situation of small scale production systems prevailing in rural areas.

Data on station experimentation with animals fed on low quality roughage show improved performance and satisfactory fattening performance for both Small East African (SEA) and crossbred goats when they are supplemented with concentrate feeds (Hango et al., 2007; Mushi et al., 2009; Safari et al., 2009). However how these goats will perform in fattening dietary regime under small scale farming conditions in Tanzania is yet to be documented. However there are no studies, focusing on meat quality attributes of goats in connection with feeding and post slaughter handling of carcasses. Results of on station studies have seldom been extended to on farm verification. This being the case, replicability of on station results should be done under prevailing small scale farming conditions.

Differences in meat quality attributes in cattle and small ruminants caused by breed, feeding and management practices has been reported by Shija et al. (2013) who concluded that feedlot strategies under traditional animal production systems in the rural areas in the tropics may be different from that of modern production systems using improved breeds of animals. Concentrate supplementation besides having high feeding value, improves the utilization of roughage fed with them. Kochapakdee et al. (1994) have reported the importance of concentrate supplementation in growth and productivity of sheep and goats in a pasture based grazing. They further stressed on the need to study the quality of meat of goat from different breeds of goats under existing feeding systems in rural areas in order to come with appropriate improvement strategies for feedlotting goats. The aim of the experiment was therefore to study the effect of feeding forage alone or in combination with different levels of concentrate on meat quality characteristics of SEA goats and their crosses with Norwegian Goats under small scale farming system.

\section{MATERIALS AND METHODS}

\section{Location of the study}

The study was carried out in Gairo division in Kilosa district, Morogoro region, Tanzania. The altitude of the division ranges between 1,076 to $1,631 \mathrm{~m}$ above sea level. Gairo is characterized by unreliable and poorly distributed rains. The area receives an average of 600 to $800 \mathrm{~mm}$ of rain annually.

\section{Animals and management}

The study comprised of two breeds of goats i.e. SEA goats and their crosses with Norwegian $(\mathrm{SEA} \times \mathrm{N})$. The experimental animals at the age of 18 months and live BW of $16.7 \pm 0.54 \mathrm{~kg}$ were purchased from auction markets in
Gairo district and transported to a farm owned by a goat keeper in the area for effecting the experiment. Twenty four goats from each breed $(\mathrm{SEA}$ and $\mathrm{SEA} \times \mathrm{N})$ were distributed in a completely randomized design in a $2 \times 3$ factorial arrangement (two breed and three dietary treatments). The three dietary treatments were; no access to concentrate (T0), $66 \%$ access to ad libitum concentrate allowance (T66) and $100 \%$ access to ad libitum concentrate allowance with $20 \%$ refusal (T100) respectively. The feeding trial extended for a period of $84 \mathrm{~d}$. In addition, all animals were offered hay ad libitum throughout the experimental period.

\section{Feeds and feeding of animals}

The concentrate consisted of $70 \%$ maize bran, $28 \%$ sunflower seedcake, $1.3 \%$ lime, $0.5 \%$ mineral-vitamins mixture and $0.2 \%$ table salt (Table 1 ). During the adaptation period of $14 \mathrm{~d}$, all goats were protected against internal and external parasites with Ivermectin. During the same period goats were group fed with hay ad libitum and in addition, those on T66 and T100 received $200 \mathrm{~g}$ of concentrate per goat per day in order for the animals to get used to the diet. Animals were grazed on pastures around the farm from 1000 to $1200 \mathrm{~h}$ after which they were brought back to their group feeding pens (four animals per pen) and animals had free access to drinking water. Feeding of concentrates and hay were done twice a day in two equal portions at $0830 \mathrm{~h}$ in the morning before grazing and in the afternoon at 1430 h. Feed intake was obtained by difference between feed offered and refusal. However, quantity of feed during grazing period was not possible. During experimentation, three goats (two from $\mathrm{SEA} \times \mathrm{N}$ crossbred and one from SEA) died from Orf disease (Contagious Ecthyma).

\section{Slaughter procedure, carcass grading and measurements}

Goats were slaughtered after $16 \mathrm{~h}$ fasting with access to

Table 1. Chemical composition of concentrate, grass hay and sward

\begin{tabular}{lccc}
\hline Component (g/kg dry matter) & Concentrate & Grass hay & Sward \\
\hline Dry matter & 944.5 & 956.7 & 947.8 \\
Organic matter & 923.7 & 951.4 & 913.8 \\
Ash & 72.1 & 46.5 & 81.7 \\
Crude protein & 143.7 & 41.0 & 106.9 \\
Ether extracts & 91.1 & 5.5 & 6.6 \\
Crude fibre & 141.9 & 359.1 & 268.3 \\
Nitrogen free extract & 495.7 & 504.6 & 484.3 \\
Neutral detergent fibre & 410.6 & 791.4 & 662.7 \\
Acid detergent fibre & 170.8 & 481.5 & 365.8 \\
In vitro dry matter digestibility & 540 & 404 & 391 \\
In vitro organic matter & 553 & 411 & 373 \\
$\quad$ digestibility & & & \\
Metabolizable energy & 12.2 & 9.5 & 9.6 \\
(MJ/kg DM) & & & \\
\hline
\end{tabular}


drinking water in the halal method according to Islamic tradition in which the head was removed at the atlantooccipital joint and forefeet at the carpal-metacarpal joint and hind feet at the tarsal-metatarsal joint. Subsequently, the carcasses were divided longitudinally into two halves. Dressing percentages (DP) was calculated as the hot carcass weight $(\mathrm{HCW})$ expressed as a percentage of empty body weight (True DP) or as a percentage of slaughter body weight (Commercial DP). Kidneys, kidney fat and pelvic fat were included in the definition of carcass. Carcasses were then scored for conformation (scale from $\mathrm{E}=$ excellent to $\mathrm{P}=$ poor) and fatness (scale from $1=$ none or low fat cover to 5 = entire carcass covered with fat) based on EUROP classification system for goats (Johansen et al., 2006). Each of the five classes for conformation and fatness were divided into three subclasses;,- 0 , or + to form 15 grades, Grade 1 is $\mathrm{P}$ - for conformation class and 1 - for fat class. Grade 15 is E+ for conformation class and 5+ for fat class. Omental fat, mesenteric fat, kidney fat, pelvic fat, heart fat and scrotal fat were removed and weighed separately. Various linear measurements which were taken on the right half-carcasses were; internal carcass length (from the lumbo-sacrajoint to the cervico-thoracic joint), carcass depth (from the dorsal to the ventral edges of the carcass side along the 9th rib), hind leg length (from the ridge of the distal end of the tibia to the cut edge of the subcutaneous fat along a line joining the anterior pubic symphysis), and hind leg circumference (Moran and Wood, 1986). A digital thermometer and portable $\mathrm{pH}$-meter (Knick-portamess 910, Germany) were used to measure temperature and $\mathrm{pH}$ of meat at $45 \mathrm{~min}, 6 \mathrm{~h}$ and $24 \mathrm{~h}$ after being chilled at $0^{\circ} \mathrm{C}$ at the same point on the geometric centre of M. Gluteobiceps of the right half carcasses.

\section{Muscle sampling for physico-chemical properties and carcass composition}

Ten muscles namely; Semimembranosus, Semitendinosus, Gluteobiceps, Vastus lateralis, Rectus abdominis, Longismuss dorsi (LD), Psoas major, Supraspinatus, Infraspinatus, and Triceps branchii were excised from the left half of carcasses $6 \mathrm{~h}$ post-mortem (PM). Further, LD muscle was split into 3 blocks measuring $7 \mathrm{~cm}$ long. They were then assigned to 0,6 , and 9 days of ageing and stored in plastic bags. The muscles were weighed before being stored in a refrigerator set at $4{ }^{\circ} \mathrm{C}$ overnight. The LD samples for ageing remained in the refrigerator for $6 \mathrm{~h}$ (0 day), 6 and 9 days respectively before shifting into the freezer. The remaining parts of the left halfcarcasses were dissected into muscle, fat and bone to estimate the carcass physical composition. Total weight of muscle was recorded and included weights of the ten muscles sampled at $6 \mathrm{~h}$ PM. Thereafter, muscle and fat tissues were thoroughly mixed together; minced $(5 \mathrm{~mm}$ sieve) and three sub-samples were taken for chemical analyses according to AOAC (2000).

\section{Estimation of thawing loss, cooking loss and Warner- Bratzler shear force}

Each frozen muscle was weighed (W1), thawed at $4^{\circ} \mathrm{C}$ for $24 \mathrm{~h}$. The bag was opened and muscles were then blotted dry with filter paper and weighed (W2). Thawing loss (\%) was calculated as; ([W1-W2/W1) $\times 100$. For determination of cooking loss, samples were weighed (W3) in the water tight vacuum packed bags and then cooked in thermostatically controlled water bath (Fisher scientific, Pittsburgh, PA, USA) set at $75^{\circ} \mathrm{C}$ for $60 \mathrm{~min}$ as described by Hoffman et al. (2003). Following cooking, meat samples were cooled for $4 \mathrm{~h}$ and samples were taken from the bags dried with filter paper and reweighed (W4). Cooking loss was expressed as the percentage loss related to initial weight: ([W3-W4]/W3)×100. Three sub-samples, cut parallel to the muscle fibres direction with a cross section of $1 \times 1 \mathrm{~cm}$, were removed from each cooked muscle sample. Shear force values of sub-samples were determined using a Zwick/Roell (Z2.5, Ulm, Germany) equipped with a Warner Bratzler (WB). Each sub-sample obtained from cooked muscle sample was sheared twice and the forces obtained were recorded. Each sample was measured twice and a mean value was calculated as maximum shear force value.

\section{Statistical analysis}

Data were analyzed using the general linear model procedure of 9.2 version (SAS, 2002), for the effect of breed and dietary treatment on meat quality attributes. For carcass grading and meat quality, slaughter weight was used as covariate. Each animal served as an experimental unit for all the parameter assessed. Further, in the analysis of muscle physico-chemical properties fixed effects included breed, dietary treatment, muscle type and their interaction. In all analyses, when differences between means were significant in analysis of variance, they were separated by probability differences statement at $\mathrm{p}<0.05$.

\section{RESULTS}

\section{Feed intake}

Grass hay dry matter (DM) intake declined from T0 by 0.32 and $0.39 \mathrm{~kg}$ for T66 and T100 goats, respectively, with corresponding increased concentrate DM intake by 0.03 and $0.14 \mathrm{~kg}$ (Table 2). The ad libitum concentrate intake of animals was $536 \mathrm{~g} / \mathrm{d}$, which was $183 \mathrm{~g} / \mathrm{d}$ higher than the concentrate intake by goats in T100 and those in T66 and T0 was 123.9 and $154 \mathrm{~g} / \mathrm{d}$, respectively. The DM intake of grass hay and its metabolizable energy (ME) declined as a amount of concentrate increased. The results showed that the animals in T100 had very little hay intake which 
Table 2. Means for feed intakes and DM intake (\% live weight) of castrated SEA $\times \mathrm{N}$ and SEA goats under different levels of concentrate supplementation

\begin{tabular}{|c|c|c|c|c|c|}
\hline \multirow{2}{*}{ Variable } & \multicolumn{2}{|c|}{ Breed (B) } & \multicolumn{3}{|c|}{ Diet (D) } \\
\hline & $\mathrm{SEA} \times \mathrm{N}$ & SEA & T0 & T66 & T100 \\
\hline \multicolumn{6}{|l|}{ Feed intake (g DM/d) } \\
\hline Concentrate & 454.1 & 435.1 & - & 352.9 & 536.3 \\
\hline Hay & 351.2 & 324.1 & 459.8 & 137.5 & 78 \\
\hline Total feed intake & 805.3 & 759.2 & 459.8 & 490.4 & 614.3 \\
\hline \multicolumn{6}{|c|}{ Metabolizable energy MJ (ME/d) } \\
\hline Concentrate & 5.5 & 5.3 & - & 4.3 & 6.5 \\
\hline Hay & 3.3 & 3.1 & 4.4 & 1.3 & 0.7 \\
\hline Total ME intake & 8.9 & 8.4 & 4.4 & 5.6 & 7.2 \\
\hline Intake ( $\%$ body weight) & 4.3 & 4.2 & 2.7 & 2.6 & 3.2 \\
\hline FCR (kg DM feed/gain) & 27.5 & 35.3 & 39.8 & 12.2 & 10.8 \\
\hline
\end{tabular}

DM, dry matter; SEA $\times$, small East African $\times$ Norwegian goats; SEA, small East African goats; T0, grazing+hay supplementation; T66, grazing+hay supplementation $+66 \%$ of ad libitum concentrate; T100, grazing+hay supplementation+100\% of ad libitum concentrate; ME, metabolizable energy; FCR, feed conversion ratio.

constituted $12.7 \%$ of total intake. Efficiency feed utilization improved with concentrate supplementation, and T66 and T100 animals had better feed conversion ratio, almost three fold than that in T0.

\section{Carcass yield, grading and classification}

Genotype had a significant $(\mathrm{p}<0.05)$ effect on $\mathrm{HCW}$, True and Commercial DP with SEA goats having the highest $(\mathrm{p}<0.05)$ HCW and DP (Table 3). The DP ranged from $52.7 \%$ to $54.9 \%$ and $37.2 \%$ to $45.7 \%$ for True and Commercial DP respectively. Diet had a significant effect $(\mathrm{p}<0.001)$ on Commercial DP and True DP $(\mathrm{p}<0.01)$. There was no significant difference observed for carcass conformation among supplemented goats but fatness score of the carcasses increased $(p<0.05)$ with level of concentrate supplementation. Hind leg circumference $(\mathrm{cm})$ was highly $(\mathrm{p}<0.001)$ affected by diet. Supplemented goats displayed comparable and greater values $(\mathrm{p}<0.05)$ for hind leg circumference than that of non-supplemented goats.

\section{Fat depots}

Goats fed on T100 had more fat depot than T66 except weight of kidney and pelvic fat were similar and higher than weight obtained in no supplemented goats (Table 4). The weight of the omental fat and total fat depot increased $(p<0.05)$ with level of concentrate on offer. When depot were expressed as percentage of slaughter weight the score were four fold higher compared to those obtained from

Table 3. Carcass grading and measurement of castrated SEA $\times N$ and SEA goats under different levels of concentrate supplementation

\begin{tabular}{|c|c|c|c|c|c|c|c|c|}
\hline \multirow{2}{*}{ Variable } & \multicolumn{2}{|c|}{ Breed (B) } & \multicolumn{3}{|c|}{ Diet (D) } & \multicolumn{3}{|c|}{ Significance } \\
\hline & $\mathrm{SEA} \times \mathrm{N}$ & SEA & T0 & T66 & T100 & B & $\mathrm{D}$ & $\mathrm{B} \times \mathrm{D}$ \\
\hline \multicolumn{9}{|l|}{ Body weight (kg) } \\
\hline Initial & $16.8 \pm 0.5$ & $16.6 \pm 0.5$ & $16.7 \pm 0.7$ & $16.8 \pm 0.6$ & $16.5 \pm 0.6$ & NS & NS & NS \\
\hline Final & $19.9 \pm 0.5$ & $19.4 \pm 0.4$ & $17.7 \pm 0.6^{\mathrm{b}}$ & $20.3 \pm 0.5^{\mathrm{a}}$ & $21.0 \pm 0.5^{\mathrm{a}}$ & NS & $* *$ & NS \\
\hline Hot carcass & $7.9 \pm 0.1^{\mathrm{b}}$ & $8.2 \pm 0.1^{\mathrm{a}}$ & $7.1 \pm 0.1^{\mathrm{b}}$ & $8.3 \pm 0.1^{\mathrm{a}}$ & $8.6 \pm 0.1^{\mathrm{a}}$ & $*$ & $* * *$ & NS \\
\hline \multicolumn{9}{|l|}{ Dressing percentage (DP) } \\
\hline True DP & $53.3 \pm 0.3^{\mathrm{b}}$ & $54.5 \pm 0.3^{\mathrm{a}}$ & $52.7 \pm 0.5^{\mathrm{b}}$ & $54.1 \pm 0.4^{\mathrm{a}}$ & $54.9 \pm 0.4^{\mathrm{a}}$ & $* *$ & $* *$ & NS \\
\hline Commercial DP & $41.6 \pm 0.5^{\mathrm{b}}$ & $43.3 \pm 0.5^{\mathrm{a}}$ & $37.2 \pm 0.7^{\mathrm{b}}$ & $44.3 \pm 0.6^{\mathrm{a}}$ & $45.7 \pm 0.6^{\mathrm{a}}$ & $*$ & $* * *$ & NS \\
\hline \multicolumn{9}{|l|}{ EUROP grading(1-15 points) } \\
\hline Conformation & $5.6 \pm 0.3$ & $5.6 \pm 0.3$ & $3.5 \pm 0.4^{\mathrm{b}}$ & $6.2 \pm 0.3^{\mathrm{a}}$ & $7.0 \pm 0.4^{\mathrm{a}}$ & NS & $* * *$ & NS \\
\hline Fatness & $5.7 \pm 0.5$ & $5.8 \pm 0.5$ & $2.6 \pm 0.7^{\mathrm{c}}$ & $6.2 \pm 0.6^{\mathrm{b}}$ & $8.5 \pm 0.6^{\mathrm{a}}$ & NS & $* * *$ & NS \\
\hline \multicolumn{9}{|c|}{ Linear carcass measurements $(\mathrm{cm})$} \\
\hline Carcass length & $51.4 \pm 0.3$ & $50.5 \pm 0.3$ & $50.8 \pm 0.5$ & $51.1 \pm 0.4$ & $51.0 \pm 0.4$ & NS & NS & NS \\
\hline Carcass depth & $23.3 \pm 0.4$ & $22.9 \pm 0.4$ & $23.3 \pm 0.5$ & $23.1 \pm 0.4$ & $22.9 \pm 0.5$ & NS & NS & NS \\
\hline Hind leg length & $35.5 \pm 0.6$ & $36.8 \pm 0.6$ & $37.9 \pm 0.9$ & $35.4 \pm 0.7$ & $35.3 \pm 0.8$ & NS & NS & $*$ \\
\hline Hind leg circumference & $28.6 \pm 0.4$ & $29.3 \pm 0.4$ & $26.9 \pm 0.5^{b}$ & $29.7 \pm 0.4^{\mathrm{a}}$ & $30.2 \pm 0.5^{\mathrm{a}}$ & NS & $* * *$ & NS \\
\hline
\end{tabular}

SEA $\times N$, small East African $\times$ Norwegian goats; SEA, small East African goats; T0, grazing+hay supplementation; T66, grazing+hay supplementation $+66 \%$ of ad libitum concentrate; T100, grazing+hay supplementation+100\% of ad libitum concentrate; NS, non significant.

${ }^{a b c}$ Least square means with different superscripts within breed and diet in the same row differ $(\mathrm{p}<0.05)$ according to the indicated level of significance.

$* \mathrm{p}<0.05 ; * * \mathrm{p}<0.01 ; * * * \mathrm{p}<0.001$. 
Table 4. Fat depots in castrated SEA $\times N$ and SEA goats under different levels of concentrate supplementation

\begin{tabular}{|c|c|c|c|c|c|c|c|c|}
\hline \multirow{2}{*}{ Variable } & \multicolumn{2}{|c|}{ Breed (B) } & \multicolumn{3}{|c|}{ Diet (D) } & \multicolumn{3}{|c|}{ Significance } \\
\hline & $\mathrm{SEA} \times \mathrm{N}$ & SEA & T0 & T66 & T100 & $\mathrm{B}$ & $\mathrm{D}$ & $\mathrm{B} \times \mathrm{D}$ \\
\hline \multicolumn{9}{|l|}{ Weights (g) } \\
\hline Kidney fat & $68.0 \pm 9.10$ & $67.4 \pm 8.89$ & $26.2 \pm 12.74^{\mathrm{b}}$ & $76.26 \pm 10.62^{a}$ & $100.6 \pm 10.96^{\mathrm{a}}$ & NS & $* * *$ & NS \\
\hline Pelvic fat & $63.4 \pm 9.52$ & $72.3 \pm 9.30$ & $18.4 \pm 13.32^{\mathrm{b}}$ & $78.1 \pm 11.10^{\mathrm{a}}$ & $107.0 \pm 11.46^{\mathrm{a}}$ & NS & $* * *$ & NS \\
\hline Mesenteric & $42.6 \pm 5.37$ & $30.9 \pm 5.24$ & $21.1 \pm 7.51^{\mathrm{b}}$ & $32.4 \pm 6.26^{\mathrm{b}}$ & $56.7 \pm 6.46^{\mathrm{a}}$ & NS & $* *$ & NS \\
\hline Omental fat & $188.1 \pm 26.62$ & $230.7 \pm 26.01$ & $92.3 \pm 37.26^{\mathrm{c}}$ & $215.5 \pm 31.05^{\mathrm{b}}$ & $320.4 \pm 32.05^{\mathrm{a}}$ & NS & $* * *$ & NS \\
\hline Heart fat & $16.0 \pm 4.18$ & $20.5 \pm 4.08$ & $7.3 \pm 5.85^{\mathrm{b}}$ & $16.2 \pm 4.87^{\mathrm{b}}$ & $31.2 \pm 5.03^{\mathrm{a}}$ & NS & $*$ & NS \\
\hline Scrotal fat & $41.5 \pm 6.01$ & $46.4 \pm 5.88$ & $19.9 \pm 8.42^{\mathrm{b}}$ & $40.6 \pm 7.01^{\mathrm{b}}$ & $71.3 \pm 7.24^{\mathrm{a}}$ & NS & $* * *$ & NS \\
\hline Total fat depots (kg) & $0.4 \pm 0.05$ & $0.5 \pm 0.05$ & $0.2 \pm 0.07^{\mathrm{c}}$ & $0.5 \pm 0.06^{\mathrm{b}}$ & $0.7 \pm 0.06^{\mathrm{a}}$ & NS & $* * *$ & NS \\
\hline Depot $\%$ SWT & $2.1 \pm 0.23$ & $2.3 \pm 0.23$ & $0.7 \pm 0.33^{c}$ & $2.3 \pm 0.27^{\mathrm{b}}$ & $3.4 \pm 0.28^{\mathrm{a}}$ & NS & $* * *$ & NS \\
\hline
\end{tabular}

SEA $\times N$, small East African $\times$ Norwegian goats; SEA, small East African goats; T0, grazing+hay supplementation; T66, grazing+hay supplementation $+66 \%$ of ad libitum concentrate; T100, grazing+hay supplementation $+100 \%$ of ad libitum concentrate; NS, non significant; SWT, slaughter weight.

${ }^{a b c}$ Least square means with different superscripts within breed and diet in the same row differ $(\mathrm{p}<0.05)$ according to the indicated level of significance

$* \mathrm{p}<0.05 ; * * \mathrm{p}<0.01 ; * * * \mathrm{p}<0.001$.

goats fed T0.

\section{Carcass physical and chemical compositions}

There was no significant ( $p>0.05$ ) effect of breed on carcass physical composition (Table 5). Based on dietary levels, the mean proportions of the various carcass tissues ranged from $64 \%$ to $67 \%, 3 \%$ to $15 \%$, and $21 \%$ to $30 \%$ for muscle, fat and bone respectively. Dietary levels had a significant effect $(p<0.001)$ on proportion of fat and bone of carcasses. Fat as percent of carcass increased $(p<0.05)$ with increasing level concentrate in the diet. As expected, goats fed T100 had highest $(\mathrm{p}<0.05)$ proportion of fat and lowest $(\mathrm{p}<0.05)$ proportion of bone followed by T66 and T0. On the other hand, the proportion of bone decreased $(p<0.05)$ with increasing carcass fat.

Dietary levels had highly significant $(\mathrm{p}<0.001)$ on percentage of DM, moisture, ash, protein and fat. Concentrate supplemented goats had similar values for ash, protein and fat contents, lower $(\mathrm{p}<0.05)$ values for ash and protein but higher $(\mathrm{p}<0.05)$ value for fat content than nonsupplemented goats. In addition, increasing levels of concentrates on offer increased $(p<0.05)$ DM of the meat but decreased $(p<0.05)$ content of water in the meat.

\section{Post-mortem temperature and $\mathrm{pH}$ decline}

Muscle temperature and $\mathrm{pH}$ were independent $(\mathrm{p}>0.05)$ of breed effect during PM temperature decline (Table 6). Differences in temperature between carcasses from goats fed different levels of concentrate were significant at 45 $\min (\mathrm{p}<0.01)$ and $6 \mathrm{~h}(\mathrm{p}<0.001)$ but were not significant at $24 \mathrm{~h}$ PM. Carcass temperature for goats under T0 was lower $(\mathrm{p}<0.05)$ up to $6 \mathrm{~h}$ PM. Similarly, the effect of dietary levels on $\mathrm{pH}$ decline at different times $\mathrm{PM}$ was significant $(\mathrm{p}<0.05)$ at $45 \mathrm{~min}$ and $6 \mathrm{~h}$. Ultimate $\mathrm{pH}$ measured at $24 \mathrm{~h}$ PM did not differ between carcasses from different dietary levels. Muscle $\mathrm{pH}$ of goats fed concentrate declined rapidly

Table 5. Carcass physical and chemical compositions of castrated SEA $\times N$ and SEA goats under different levels of concentrate supplementation

\begin{tabular}{|c|c|c|c|c|c|c|c|c|}
\hline \multirow{2}{*}{ Variable } & \multicolumn{2}{|c|}{ Breed(B) } & \multicolumn{3}{|c|}{ Diet (D) } & \multicolumn{3}{|c|}{ Significance } \\
\hline & $\mathrm{SEA} \times \mathrm{N}$ & SEA & T0 & T66 & $\mathrm{T} 100$ & G & $\mathrm{D}$ & $\mathrm{B} \times \mathrm{D}$ \\
\hline \multicolumn{9}{|c|}{ Carcass physical composition (\%) } \\
\hline Muscle & $65.3 \pm 0.77$ & $66.4 \pm 0.75$ & $66.8 \pm 1.07$ & $66.7 \pm 0.89$ & $63.9 \pm 0.92$ & NS & NS & NS \\
\hline Fat & $9.8 \pm 0.62$ & $8.4 \pm 0.61$ & $3.0 \pm 0.87^{\mathrm{c}}$ & $9.6 \pm 0.73^{\mathrm{b}}$ & $14.7 \pm 0.75^{\mathrm{a}}$ & NS & $* * *$ & NS \\
\hline Bone & $25.0 \pm 0.63$ & $25.2 \pm 0.62$ & $30.1 \pm 0.89^{\mathrm{a}}$ & $23.7 \pm 0.74^{\mathrm{b}}$ & $21.4 \pm 0.76^{\mathrm{c}}$ & NS & $* * *$ & NS \\
\hline \multicolumn{9}{|l|}{ Percentage } \\
\hline Moisture & $67.2 \pm 0.78$ & $67.7 \pm 0.76$ & $72.9 \pm 1.09^{\mathrm{a}}$ & $66.1 \pm 0.91^{\mathrm{b}}$ & $63.4 \pm 0.94^{\mathrm{c}}$ & NS & $* * *$ & NS \\
\hline Ash & $3.6 \pm 0.13$ & $3.5 \pm 0.13$ & $4.4 \pm 0.19^{\mathrm{a}}$ & $3.3 \pm 0.16^{\mathrm{b}}$ & $3.0 \pm 0.16^{\mathrm{b}}$ & NS & $* * *$ & NS \\
\hline Protein & $20.4 \pm 0.34$ & $20.8 \pm 0.34$ & $22.2 \pm 0.48^{\mathrm{a}}$ & $20.2 \pm 0.40^{\mathrm{b}}$ & $19.3 \pm 0.41^{\mathrm{b}}$ & NS & $* * *$ & NS \\
\hline Fat & $6.0 \pm 0.70$ & $5.3 \pm 0.69$ & $2.3 \pm 0.98^{\mathrm{b}}$ & $6.2 \pm 0.82^{\mathrm{a}}$ & $8.4 \pm 0.85^{\mathrm{a}}$ & NS & $* * *$ & NS \\
\hline Dry matter & $32.8 \pm 0.78$ & $32.3 \pm 0.76$ & $27.1 \pm 1.09^{c}$ & $33.9 \pm 0.91^{b}$ & $36.6 \pm 0.94^{\mathrm{a}}$ & NS & $* * *$ & NS \\
\hline
\end{tabular}

SEA $\times \mathrm{N}$, small East African $\times$ Norwegian goats; SEA, small East African goats; T0, grazing+hay supplementation; T66, grazing+hay supplementation $+66 \%$ of ad libitum concentrate; T100, grazing+hay supplementation+100\% of ad libitum concentrate; NS, non significant.

${ }^{a b c}$ Least square means with different superscripts within breed and diet in the same row differ $(\mathrm{p}<0.05)$ according to the indicated level of significance. $* * * \mathrm{p}<0.001$ 
Table 6. Post-mortem temperature and $\mathrm{pH}$ decline in carcasses of castrated SEA $\times \mathrm{N}$ and SEA goats under different levels of concentrate supplementation

\begin{tabular}{|c|c|c|c|c|c|c|}
\hline \multirow{2}{*}{ Variable } & \multicolumn{3}{|c|}{ Temperature } & \multicolumn{3}{|c|}{$\mathrm{pH}$} \\
\hline & $45 \mathrm{~min}$ & $6 \mathrm{~h}$ & $24 \mathrm{~h}$ & $45 \mathrm{~min}$ & $6 \mathrm{~h}$ & $24 \mathrm{~h}$ \\
\hline \multicolumn{7}{|l|}{ Breed (B) } \\
\hline $\mathrm{SEA} \times \mathrm{N}$ & $32.8 \pm 0.48$ & $27.9 \pm 0.15$ & $4.5 \pm 0.16$ & $6.5 \pm 0.07$ & $5.9 \pm 0.05$ & $5.8 \pm 0.05$ \\
\hline SEA & $32.7 \pm 0.47$ & $27.6 \pm 0.15$ & $4.7 \pm 0.15$ & $6.4 \pm 0.07$ & $6.0 \pm 0.05$ & $5.8 \pm 0.05$ \\
\hline \multicolumn{7}{|l|}{ Diet (D) } \\
\hline T0 & $30.8 \pm 0.62^{b}$ & $26.8 \pm 0.21^{\mathrm{b}}$ & $4.8 \pm 0.21$ & $6.7 \pm 0.09^{\mathrm{a}}$ & $6.1 \pm 0.07^{\mathrm{a}}$ & $5.9 \pm 0.06$ \\
\hline T66 & $33.4 \pm 0.56^{a}$ & $28.1 \pm 0.19^{\mathrm{a}}$ & $4.6 \pm 0.19$ & $6.3 \pm 0.08^{b}$ & $5.9 \pm 0.06^{\mathrm{ab}}$ & $5.8 \pm 0.06$ \\
\hline $\mathrm{T} 100$ & $34.0 \pm 0.56^{\mathrm{a}}$ & $28.4 \pm 0.19^{\mathrm{a}}$ & $4.5 \pm 0.19$ & $6.3 \pm 0.08^{b}$ & $5.8 \pm 0.06^{\mathrm{b}}$ & $5.7 \pm 0.06$ \\
\hline \multicolumn{7}{|c|}{ Significance } \\
\hline B & NS & NS & NS & NS & NS & NS \\
\hline $\mathrm{D}$ & $* *$ & $* * *$ & NS & $*$ & $*$ & NS \\
\hline$B \times D$ & NS & NS & NS & NS & NS & NS \\
\hline
\end{tabular}

SEA $\times$ N, small East African $\times$ Norwegian goats; SEA, small East African goats; T0, grazing+hay supplementation; T66, grazing+hay supplementation $+66 \%$ of ad libitum concentrate; T100, grazing+hay supplementation+100\% of ad libitum concentrate; min, minutes; h, hour; NS, non significant.

${ }^{\mathrm{ab}}$ Least square means with different superscripts within columns differ $(\mathrm{p}<0.05)$ according to the indicated level of significance.

$* \mathrm{p}<0.05 ; * * \mathrm{p}<0.01 ; * * * \mathrm{p}<0.001$.

and reached 5.9 (T66) and 5.8 (T100) at $6 \mathrm{~h} \mathrm{PM} \mathrm{but}$ temperature was still high at $28^{\circ} \mathrm{C}$ at the same time. On the other hand, muscle $\mathrm{pH}$ for T100 goats was lower $(\mathrm{p}<0.05)$ at 45 min and $6 \mathrm{~h}$ PM than that of goats fed T0.

\section{Thawing loss, cooking loss and Warner-Bratzler shear force}

Least squares means of muscle physical properties are presented in Table 7. There was no significant $(\mathrm{p}>0.05)$ effect of breed on cooking loss and shear force of muscle. The SEA goats had higher $(\mathrm{p}<0.05)$ thawing loss than $\mathrm{SEA} \times \mathrm{N}$ crossbred goats. On the other hand, thawing loss was not affected by dietary levels. Goats finished on T66 had higher $(\mathrm{p}<0.05)$ cooking loss compared to the other groups. Shear force decreased $(p<0.05)$ with concentrate supplementation, and T0 had higher $(\mathrm{p}<0.05)$ shear force values than goats fed ad libitum concentrate (T100).

There were significant differences among muscles with respect to thawing loss, cooking loss and Warner-Bratzler shear force (WBSF) (Table 6). M. Semimembranosus and LD which were analyzed without ageing had similar and highest $(\mathrm{p}<0.05)$ thawing loss followed by M. Psoas major but $M$. Rectus abdominis had the lowest $(\mathrm{p}<0.05)$ values for thawing losses followed by $M$. Triceps branchii. On the other hand, M. Supraspinatus and Semimembranosus had statistically similar and highest $(\mathrm{p}<0.05)$ values for cooking loss while lowest value was observed in M. Rectus abdominis. In addition M. Gluteobiceps and Semimembranosus had similar and highest values for shear force values, followed by $M$. Vastus lateralis and Triceps branchii. The lowest $(\mathrm{p}<0.05)$ shear force values were recorded for M. Psoas major and Infraspinatus followed by LD muscle. It is interesting to note that shear force for LD muscle decreased from $43 \mathrm{~N}$ units at day zero of aging to 36 $\mathrm{N}$ at day 9 of aging.

\section{DISCUSSION}

\section{Feed intake}

Concentrate supplementation reduced forage DM intake but increased total energy intake. Daily total ME intake for T0 goats of $4.4 \mathrm{MJ} / \mathrm{kg} \mathrm{DM}$ was below the recommended value of $5.78 \mathrm{MJ} / \mathrm{kg}$ DM (Langston University 2000). DM intake of supplemented goats in this experiment $(2.6 \%$ to $3.2 \%$ of body weight) was higher than the range reported by Hamed and Fliman (2010).

\section{Carcass yield, grading and classification}

Goats fed concentrate diets had higher values for $\mathrm{HCW}$, carcass conformation, fatness score and hind leg circumference than the forage fed ones. Results of HCW for T0 goats of $7.1 \mathrm{~kg}$ agree to range of 5.9 to $7.1 \mathrm{~kg}$ for nonsupplemented Black Bengal goats (Asaduzzaman et al., 2009). The trend for DP to increase with level of concentrate supplementation agrees with other studies (Melaku and Betsha, 2008; Liméa et al., 2009) which reported the increasing DP with concentrate supplementation in the diet. The superior DP found in heavier goats is associated with high energy intake (Mahgoub et al., 2005). Lack of significant differences of True DP among goats that fed on concentrate based diet are also reported by Hango et al. (2007) who did not find differences between different feeding regimes for this trait in SEA goats. True DP of the goats in the present study was similar to $51 \%$ to $54 \%$ for male goats of six genotypes (Dhanda et al., 2003). Differences in DP for two breeds 
Table 7. Thawing loss, cooking loss and warner-bratzler shear force of muscles in castrated SEA $\times \mathrm{N}$ and SEA goats under different levels of concentrate supplementation

\begin{tabular}{|c|c|c|c|}
\hline Variable & $\begin{array}{c}\text { Thawing } \\
\text { loss } \%\end{array}$ & $\begin{array}{c}\text { Cooking } \\
\text { loss } \%\end{array}$ & $\begin{array}{l}\text { Shear force } \\
\text { (N) }\end{array}$ \\
\hline \multicolumn{4}{|l|}{ Breed (B) } \\
\hline SEA $\times N$ & $5.77 \pm 0.16^{\mathrm{b}}$ & $25.69 \pm 0.29$ & $47.40 \pm 0.55$ \\
\hline SEA & $6.36 \pm 0.15^{\mathrm{a}}$ & $25.33 \pm 0.28$ & $47.94 \pm 0.52$ \\
\hline \multicolumn{4}{|l|}{ Diet (D) } \\
\hline T0 & $5.96 \pm 0.20$ & $25.17 \pm 0.37^{\mathrm{b}}$ & $49.32 \pm 0.69^{\mathrm{a}}$ \\
\hline T66 & $5.97 \pm 0.18$ & $26.28 \pm 0.33^{\mathrm{a}}$ & $47.54 \pm 0.62^{\mathrm{ab}}$ \\
\hline $\mathrm{T} 100$ & $6.26 \pm 0.18$ & $25.09 \pm 0.34^{\mathrm{b}}$ & $46.15 \pm 0.64^{b}$ \\
\hline \multicolumn{4}{|l|}{ Muscles } \\
\hline LD-0D & $8.61 \pm 0.37^{\mathrm{b}}$ & $24.35 \pm 0.69^{\mathrm{d}}$ & $42.97 \pm 1.31^{\mathrm{d}}$ \\
\hline LD-6D & $9.76 \pm 0.37^{\mathrm{ab}}$ & $21.76 \pm 0.69^{\mathrm{e}}$ & $42.00 \pm 1.31^{\mathrm{d}}$ \\
\hline LD-9D & $10.26 \pm 0.37^{\mathrm{a}}$ & $22.77 \pm 0.69^{\mathrm{de}}$ & $36.34 \pm 1.31^{\mathrm{e}}$ \\
\hline Psoas major & $6.97 \pm 0.37^{\mathrm{c}}$ & $28.80 \pm 0.69^{c}$ & $34.96 \pm 1.31^{\mathrm{e}}$ \\
\hline Rectus abdominis & $1.05 \pm 0.37^{\mathrm{g}}$ & $5.54 \pm 0.69^{\mathrm{f}}$ & NA \\
\hline Triceps branchii & $3.62 \pm 0.37^{f}$ & $27.97 \pm 0.69^{c}$ & $54.90 \pm 1.31^{\mathrm{b}}$ \\
\hline Infraspinatus & $4.06 \pm 0.37^{\mathrm{ef}}$ & $24.79 \pm 0.69^{\mathrm{d}}$ & $36.36 \pm 1.31^{\mathrm{e}}$ \\
\hline Supraspinatus & $5.62 \pm 0.37^{\mathrm{d}}$ & $32.09 \pm 0.69^{\mathrm{a}}$ & $48.87 \pm 1.31^{\mathrm{c}}$ \\
\hline Semimembranosus & $8.98 \pm 0.37^{b}$ & $31.30 \pm 0.69^{\mathrm{ab}}$ & $65.56 \pm 1.31^{\mathrm{a}}$ \\
\hline Semitendinosus & $3.87 \pm 0.37^{\mathrm{ef}}$ & $28.54 \pm 0.69^{c}$ & $47.18 \pm 1.31^{\mathrm{c}}$ \\
\hline Vastus lateralis & $4.86 \pm 0.37^{\mathrm{de}}$ & $29.53 \pm 0.69^{\mathrm{bc}}$ & $58.20 \pm 1.31^{\mathrm{b}}$ \\
\hline Gluteobiceps & $5.13 \pm 0.37^{\mathrm{d}}$ & $28.71 \pm 0.69^{c}$ & $66.66 \pm 1.31^{\mathrm{a}}$ \\
\hline \multicolumn{4}{|l|}{ Significance } \\
\hline Breed(B) & $* *$ & NS & NS \\
\hline Diet (D) & NS & $*$ & $* *$ \\
\hline Muscle (M) & $* * *$ & $* * *$ & $* * *$ \\
\hline $\mathrm{B} \times \mathrm{D}$ & $* * *$ & $* * *$ & NS \\
\hline $\mathrm{B} \times \mathrm{M}$ & NS & NS & NS \\
\hline $\mathrm{D} \times \mathrm{M}$ & $* * *$ & $*$ & NS \\
\hline $\mathrm{B} \times \mathrm{D} \times \mathrm{M}$ & NS & NS & NS \\
\hline
\end{tabular}

SEA $\times \mathrm{N}$, small East African $\times$ Norwegian goats; SEA, small East African goats; T0, grazing+hay supplementation; T66, grazing+hay supplementation $+66 \%$ of ad libitum concentrate; T100, grazing+hay supplementation $+100 \%$ of ad libitum concentrate; LD-0D, Longismus. dorsi unaged; LD-6D, Longismuss dorsi aged for 6 days; LD-9D, Longismuss dorsi aged for 9 days; NA, not analysed; NS, non significant

abcdefg Least square means with different superscripts within columns differ $(p<0.05)$ according to the indicated level of significance.

$* \mathrm{p}<0.05 ; * * \mathrm{p}<0.01 ; * * * \mathrm{p}<0.001$.

observed in the present study agrees with previous work which reported significant difference between various goat breeds for DP based on full body weight (Dhanda et al., 2003).

The higher scores for conformation in supplemented animals can be associated with concentrate allowance which resulted into higher energy intake for muscle development and carcass fat deposition. The carcass conformation and fatness scores for supplemented goats were 6.2 to 7.0 and 6.2 to 8.5 respectively and these values are within the range of 4.2 to 9.5 and 5.1 to 10.1 (Mushi et al., 2009; Safari et al., 2009). Hind leg circumference of goats under T100 was greater by $3.3 \mathrm{~cm}$ than those under T0 goats. Values of most carcass measurements in the present study were similar to values reported by Safari et al. (2009) using goats of similar carcass weights.

\section{Fat depots}

The trends for accumulation of fat depots were increasing with increasing amount of concentrate in the diet. The observed highest weight of kidney and omental fat in the present study agrees with the range of 0.02 to $0.2 \mathrm{~kg}$ and 0.03 to $0.4 \mathrm{~kg}$ for kidney and omental fat reported by Lapenga et al. (2009). Furthermore, weight values of kidney and omental fat for supplemented goats were higher compared to values of 12 to $13 \mathrm{~g}$ and 20 to $30 \mathrm{~g}$ of Creole goat reported by Alexandre et al. (2009). However, Daskiran et al. (2010) reported higher omental fat of 0.91 $\mathrm{kg}$ for Norduz male goats under semi intensive system, a value which is three times more than the value of $0.32 \mathrm{~kg}$ on goats under T100 in the current study. The difference in the fat depots reported by different workers can mainly be ascribed to level of feeding, age at fattening and breed characteristics.

\section{Carcass physical and chemical compositions}

The observed higher proportion of muscle and fat from concentrate supplemented goats compared to nonsupplemented ones might be due to heavier carcasses in the former than in the latter. In the present study, T100 goats were fatter with lower proportion of bone. These findings are explained by the lower carcass weight of nonsupplemented goats where the weight of bones accounted for a significant proportion. The observed proportions of $21 \%$ to $32 \%$ and $3 \%$ to $15 \%$, bone and fat respectively in the present study are within the range reported for SEA $\times \mathrm{N}$ crossbred goats as reported by other workers (Mushi et al., 2009). The increase of fat proportion with increasing concentrate level in the diet agree with findings with Somali goats fed hay with graded levels of peanut cake and wheat bran mixture (Melaku and Betsha, 2008). These observations might be due to higher levels of energy content in the concentrate supplemented goats (Table 1). Lean meat percentages are in agreement with findings from Borana and Arsi-Bale goats under different duration of feedlot management (Dadi et al., 2005).

Dry matter and fat of meat increased with increasing concentrate on offer and hence increasing weight but the content of moisture, ash and protein followed the reverse order. Hatendi et al. (1992) also reported a decline in moisture contents of goat meat with increasing weight. The range of $19 \%$ to $22 \%$ for protein content observed from the current study was comparable to the report of young goats of Majorera breed (ArqÜello et al., 2005). The observed higher levels of chemically determined fat in carcasses 
produced by supplemented goats are due to higher intake of energy from concentrate. These findings agree with various reports comparing effects of dietary energy density on carcass composition (Diaz et al., 2002; Santos-Silva et al., 2002). The higher value of fat in the meat for concentrate supplemented goats basically could be caused for its lower proportion of water, protein and ash than non-supplemented goats. Moreover, the higher fat content of $(6.2 \%$ to $8.4 \%$ vs $4.3 \%$ to $5.1 \%$ ) concentrate supplemented goats compared to yearling stall-fed Zaraibi goats of Egypt (El-Gallad et al., 1988 ) but lower than $10.3 \%$ to $14.0 \%$ produced by Ethiopian indigenous goats fed grainless diet varying in concentrate to roughage ratios (Sebsibe et al., 2007).

\section{Post-mortem temperature and $\mathrm{pH}$ decline}

Better meat quality, especially meat tenderness, is linked to the rate of $\mathrm{pH}$ and musculature temperature fall with time PM. Ultimate $\mathrm{pH}$ ranging from 5.49 to 5.86 in goats is considered normal (ArqÜello et al., 2005; Pratiwi et al., 2007). In the present study, the difference in carcass $\mathrm{pH}$ decline between animals fed different dietary levels could be a result of variation in their fat cover. Similarly Abdullah and Musallam (2007) observed differences on carcass temperature and $\mathrm{pH}$ decline between castrated and intact male goats with different levels of fat cover. The $\mathrm{pH}$ of 5.7 to 5.8 recorded at $24 \mathrm{~h}$ PM for supplemented goats in the current study falls within the normal range reported for goats (Shija et al., 2013). The observation of ultimate $\mathrm{pH}$ in the present study is <6.00 compared to observations reported by other workers (Safari et al., 2009). As expected, there was a decrease in $\mathrm{pH}$ and temperature with time. The difference in $\mathrm{pH}$ readings recorded at 45 minutes to 24 hours was not significant between breeds. The average $\mathrm{pHu}$ for goat carcasses at $24 \mathrm{~h}$ was not affected by level of supplementations.

\section{Thawing loss, ccoking loss and Warner-Bratzler shear force}

Apart from M. Rectus abdominis, percent cooking loss from muscles of the two breeds studied were in the range of 21.76 to 32.09 and within the normal range for goat muscles according to previous findings (Babiker et al., 1990). However, considering the similarity in ultimate $\mathrm{pH}$ of carcasses between dietary levels group, the observed differences in cooking loss in carcasses and individual muscles agree with Dhanda et al. (2003) and Pratiwi et al. (2007). The decrease in cooking loss as ageing increased was as expected because of enzymatic reactions by endogenous enzymes, such as collagenase progresses at faster rates as ageing increases (Mushi et al., 2009). The collagenase enzymes disintegrate the myofibrillar proteins and connective tissue thereby improving water holding capacity by proteins (den Hertog-Meischke et al., 1998).
Cooking loss is affected by many complex factors such as heat transfer methods and surface and internal temperature of the meat (Shija et al., 2013) but was not considered in this study. Ageing muscle for 9 days in the present study did significantly improve meat tenderness by $15.43 \%$. The observations indicate that meat tenderness of goats finished under small scale farming conditions can be improved by extended ageing time as demonstrated by previous workers (Shija et al., 2013).

On the other hand, the observed variation in thawing and cooking loss for individual muscles studied correspond with Pratiwi et al. (2007) that cooking losses are different for muscles taken from different anatomical regions. Although all dietary levels group produced relatively tender meat, supplemented goats with higher level of concentrate had more tender meat than non-supplemented goats. Results from the present study indicated that M. Gluteobiceps (66 $\mathrm{N})$, M. Semimembranosus (65 N) and M. Vastus lateralis $(58 \mathrm{~N})$ were regarded as objectionably tough and the rest of muscles fall in the acceptable tender range of $<55 \mathrm{~N}$ (Abdullah and Musallum, 2007). The results in the present study are also in agreement with findings by Safari et al. (2009) and Mushi et al. (2009). However, variation of individual goat's muscles in WBSF values may be associated with their content and structure (degree of crosslinks of collagen fibres) of connective tissue due to differential involvement in physical activities (Gonzalez et al., 1983).

\section{CONCLUSION}

The present study demonstrates that there are differences in meat quality characteristics of meat from SEA goats and their crosses with Norwegian goats finished under small scale farming conditions in rural areas. Thus, effectively utilization of the available feed resources and appropriate concentrate supplementation for grazing goats appear to be the necessary steps to alleviate nutritional problems as well as improvement of goats meat quality. Therefore, concentrate supplementation of goats of both breeds improves meat quality attributes.

\section{ACKNOWLEDGMENTS}

The authors wish to thank SUA-PANTIL project 020 and the German Academic Exchange Service (DAAD) for the financial and technical support to carry out this study.

\section{REFERENCES}

Abdullah, A. Y. and H. S. Musallam. 2007. Effect of different levels of energy on carcass composition and meat quality of male black goats kids. Livest. Sci. 107:70-80. 
Agnihotri, M. K., V. Rajkumar, and T. K. Dutta. 2006. Effect of feeding complete rations with variable protein and energy levels prepared using by-products of pulses and oilseeds on carcass characteristics, meat and meat ball quality of goats. Asian Australas. J. Anim. Sci. 19:1437-1449.

Alexandre, G., R, Arquet, G. Gravillon, J. L. Weisbecker, and N. Mandonnet. 2009. Carcass characteristics of Creole goat of Guadeloupe (FWI) as a function of pre-weaning performances and post-weaning management. Livest. Res. Rural Dev. 21: Article \#57. http://www.lrrd.org/lrrd21/4/alex21057.htm. Accessed July 15, 2014.

AOAC. 2000. Official Methods of Analysis. 17th ed. Association of Official Analytical Chemist, Arlington, VA, USA.

ArqÜello, A., N. Castro, J. J. Capote, and M. Solomon. 2005. Effects of dietary levels and live weight at slaughter on kid meat quality. Meat Sci. 70:173-179.

Asaduzzaman, M., M. R. Alam, M. R. Amin, and M. O. Faruque. 2009. Comparative study on carcass characteristics between Black Bengal and crossbred goats. J. Bangladesh Agric. Univ. 7:87-90.

Babiker, S. A., I. A. Khider, and S. A. Shafie. 1990. Chemical composition and quality attributes of goat meat and lamb. Meat Sci. 28:273-277

Dadi, H., T. Woldu, and T. Lema. 2005. Comparison of carcass characteristics of Borana and Arsi-Bale goats under different durations of feedlot management. Livest. Res. Rural Dev. 17: Article \# 137. http://www.lrrd.org/lrrd17/12/dadi17137. Accessed July 15, 2014.

Daskiran, I., M. Bingol, S. Karaca, A. Yilmaz, A. O. Cetin, and A. Kor. 2010. The effect of feeding system on fattening performance, slaughter, and carcass characteristics of Norduz male kids. Trop. Anim. Health Prod. 42:1459-1463.

den Hertog-Meischke, M. J. A., F. J. M. Smulders, and J. G. van Logtestijn. 1998. The effect of storage temperature on drip loss from fresh beef. J. Sci. Food Agric. 78:522-526.

Dhanda, J.S., D. G. Taylor, and P. J. Murray. 2003. Growth, carcass and meat quality parameters of male goats: Effects of genotype and live weight at slaughter. Small Rumin. Res. 50:57-66.

Diaz, M. T., S. Velasco, V. Caneque, S. Lauzurica, F. R. de Huidobro, C. Perez, J. Gonzalez, and C. Manzanares. 2002. Use of concentrate or pasture for fattening lambs and its effect on carcass and meat quality. Small Rumin. Res. 43:257-268.

El-Gallad, T. T., S. M. Allam, E. A. Gihad, and T. M. El-Bedawy. 1988. Effect of energy intake and roughage ratio on the performance of Egyptian Nubian (Zaraibi) kids from weaning to one year of age. Small Rumin. Res. 1:343-353.

Gonzalez, F. A. N., J. E. Owen, and M. T. Arias. 1983. Studies on the Criollo goat of Northern Mexico: Part 2- physical and chemical characteristics of the musculature. Meat Sci. 9:305314.

Hamed, A. H. M. and M. E. Elimam. 2010. Perfomance and digestibility in Nubian goats fed steam treated sorghum stover. Pakistan J. Nutr. 9:298-301.

Hango, A., L. A. Mtenga, G. C. Kifaro, J. Safari, D. E. Mushi, and V. R. M. Muhikambele. 2007. A study on growth performance and carcass characteristics of Small East African goats under different feeding regimes. Livest. Res. Rural Dev. 19: Article \#130. http://www.lrrd.org/lrrd19/9/hang19130.htm. Accessed July $15,2014$.
Hatendi, P. R., T. Smith, L. Ndlovu, and C. Mutisi. 1992. Fattening mature indigenous (Matebele) goats. Effect on animals performance, body and carcass composition. In: Small Ruminant Research and Development in Africa, Proceedings of the First Biennial Conference of the African Small Ruminant Research Network (Eds. B. Rey, S. H. B. Lebbie, and L. Reynolds). ILRAD, December 10-14, 1990; Nairobi, Kenya. pp. 355-365.

Hoffman, L. C., M. Muller, S. W. P. Cloete, and D. Schmidt 2003. Comparison of six crossbred lamb types: Sensory, physical and nutritional meat quality characteristics. Meat Sci. 65:12651274.

Johansen, J., A. H. Aastveit, B. Egelandsdal, K. Kvaal, and M. Roe. 2006. Validation of EUROP system for lamb classification in Norway: Repeatability and accuracy of visual assessment and prediction of lamb carcass composition. Meat Sci. 74:497-509.

Kochapakdee, S. W., S. Pralokam, A. S. Laarpetchara, and B. W. Norton. 1994. Grazing management studies with Thai goats. I. Productivity of female goats grazing newly established pasture with varying levels of supplementary feeding. Asian Australas. J. Anim. Sci. 7:289-293.

Langston University. 2000. Goat research extension. Goat ME Requirement calculator. http://www2.luresext.edu/goats/ research/me2.html. Accessed May 15, 2010.

Lapenga, K. O., C. Ebong, and J. Opuda-Asibo. 2009. Effect of feed supplements on weight gain and carcass characteristics of intact male Mubende goats fed elephant grass (Pennisetum purpureum) ad libitum in Uganda. J. Anim. Vet Adv. 8: 20042005.

Liméa, L., M. Boval, N. Mandonnet, G. Garcia, H. Archiméde, and G. Alexandre. 2009. Growth performance, carcass quality, and noncarcass components of indigenous Caribbean goats under varying nutritional densities. J. Anim. Sci. 87:3770-3781.

Mahgoub, O., C. D. Lu, M. S. Hameed, A. Ritchie, A. S. Alhalhali, and K. Annamala. 2005. Performance of Omani goats fed diets containing various metabolizable energy densities. Small Rum. Res. 58:175-180.

Melaku, S. and S. Betsha. 2008. Body weight and carcass characteristics of Somali goats fed hay supplemented with graded levels of peanut cake and wheat bran mixture. Trop. Anim. Health Prod. 40:553-560.

Moran, J. B. and J. T. Wood. 1986. Comparative performance of 5 genotypes of Indonesian large ruminants. 3. Growth and development of carcass tissues. Aust. J. Agric. Res. 37:435447.

Mushi, D. E., L. A. Mtenga, L. O. Eik, J. Safari, and A. J. Mwilawa. 2006. Some factors affecting the quality of meat from ruminants and their relevance to the Tanzania meat industry. In: Proceedings of the 32 Scientific Conference of Tanzania Society of Animal Production, Moshi, Tanzania. 32: 109-124.

Mushi, D. E., J. Safari, L. A. Mtenga, G. C. Kifaro, and L. O. Eik. 2009. Effects of concentrate levels on fattening performance, carcass and meat quality attributes of Small East Africanx Norwegian crossbred goats fed low quality grass hay. Livest. Sci. 124:148-155.

Pratiwi, N. M. W., P. J. Murray, and D. G. Taylor. 2007. Feral goats in Australia: A study on the quality and nutritive value of their meat. Meat Sci. 75:168-177. 
Safari, J., D. E. Mushi, L. A. Mtenga, G. C. Kifaro, and L. O. Eik. 2009. Effects of concentrate supplementation on carcass and meat quality attributes of feedlot finished Small East African goats. Livest. Sci. 125:266-274.

Santos-Silva, J., L. A. Mendes, and R. J. B. Bessa. 2002. The effect of genotype, feeding system and slaughter weight on the quality of light lambs. Growth, carcass composition and meat quality. Livest. Prod. Sci. 76:17-25.

SAS. 2001. Stastical Analysis System. Users Guide, Version 8.2. SAS Institute, Inc., Cary, NC, USA.
Sebsibe, A., N. H. Casey, W. A. van Niekerk, A. Tegegne, and R. J. Coertze. 2007. Growth performance and carcass characteristics of three Ethiopian goat breeds fed grain less dietary levels varying in concentrate to roughage ratios. South Africa J. Anim. Sci. 37:221-232.

Shija, D. S., L. A. Mtenga, A. E. Kimambo, G. H. Laswai, D. E. Mushi, D. M. Mgheni, A. J. Mwilawa, E. J. M. Shirima, and J. G. Safari. 2013. Chemical composition and meat quality attributes of indigenous sheep and goats from traditional production system in Tanzania. Asian Australas. J. Anim. Sci. 26:295-302. 